\title{
The effect of above-ground medium voltage power lines on displaying site selection of the Great Bustard (Otis tarda) in Central Hungary
}

\author{
MikLÓS LóRÁNT* \& CSABA VADÁSZ
}

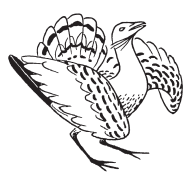

Miklós Lóránt \& Csaba Vadász 2014. The effect of above-ground medium voltage power lines on displaying site selection of the Great Bustard (Otis tarda) in Central Hungary. - Ornis Hungarica 22(2): 42-49.

Abstract Our study was conducted in the Upper-Kiskunság region, Central Hungary, which ground medium Pannonian population of the Great Bustard (Otis tarda). The influence of the presence of abovesults revealed that displaying males totally reject the sites located within $350-400 \mathrm{~m}$ or closer to medium voltage power lines as displaying sites and show relative rejection towards potential displaying sites located at a distance between 500 and $1000 \mathrm{~m}$ far from power lines. Surprisingly, the overall negative effects influence much larger part of the potential displaying grounds, up to the distance to $3500 \mathrm{~m}$ from power lines. It can be declared that power lines reduce the extent of suitable displaying sites of the Great Bustards in the Upper-Kiskunság region. Accordingly, installation of new above-ground power lines (and other kind of wires, such as high voltage power lines, optical cables etc.) would further reduce the extent of suitable displaying sites.

Keywords: Great Bustard, power lines, collision, displaying site selection

Összefoglalás Vizsgálatainkat Magyarország legnépesebb túzok (Otis tarda) populációjának élőhelyén, a Felső-Kiskunságban végeztük. Arra kerestük a választ, hogy a középfeszültségủ elektromos légvezetékek hogyan befolyásolják a túzok dürgőhely választását. Eredményeink rámutatnak arra, hogy a kakasok egyáltalán nem választanak dürgőhelyet a légvezetékek 350-400 méteres környezetében, illetve a vezetékek 500-1000 méteres környezetében is erősen alulreprezentáltak a dürgőhelyek. A teljes, illetve relatív rejekció az előbb említett távolságokban olyan erőteljes negatív hatást fejt ki a túzok kakasok dürgőhely választására, ami csak a légvezetékektöl számított 3500 méteres távolságban egyenlítődik ki. Ennek megfelelően kijelenthető, hogy a légvezetékek erőteljes fragmentáló hatással bírnak a dürgöhelyekre. Újabb légvezetékek telepítése éppen ezért össze nem egyeztethető a helyi túzokpopuláció fenntartásával.

Kulcsszavak: túzok, középfeszültségü vezeték, ütközés, dürgőhely választás

Kiskunság National Park Directorate, 6000 Kecskemét, Liszt Ferenc utca 19., Hungary, e-mail: lorantm@knp.hu "corresponding author

\section{Introduction}

Power lines represent risk of mortality caused by collision or electrocution for many bird species throughout the world, including many with endangered or vulnerable status (Bevanger 1998). While electrocution usually threatens species perching high and can be described with good flight ability, e.g. raptors, corvids, collision is generally a risk for fliers with poor manoeuvrability (Janss 2000), such as the ptarmigan species (Bevanger \& Brøseth 2001) or the bustard species (Alonso et al. 1994). Especially species with small binocular field (cranes, storks, bustards) can be characteri- 
sed with large blind areas in their visual field, thus being heavily threatened by collision (Martin \& Shaw 2010). Although there are certain possibilities for reducing the risk of collision, e.g. by changing the design of wires of power lines (Bevanger \& Brøseth 2001) or using markings and other bird flight diverters on electric wires (Alonso et al. 1994), it still represents a major killing factor in the case of certain populations (Lehman et al. 2007). Accordingly, underground cabling can be regarded as the ultimate solution for these negative impacts (Raab et al. 2012). In the case of the West-Pannonian and also the Central Hungarian Great Bustard population, collision with electric wires proved to be a major killing factor (Reiter 2000, Raab et al. 2011, Vadász \& Lóránt 2014). Even these populations are still showing slow but steady increase in population size, it can be declared that by eliminating the loss caused by collision the growth could be much more rapid.

In addition to the above mentioned effects of the power lines, these linear establishments potentially influence the habitat use of particular species by modifying the structure of open landscapes (Ballasus \& Sossinka 1996). However, it has not been studied whether the presence of power lines influence certain aspects of the habitat use of the Great Bustard or not. This species prefers large, open terrains (Lane et al. 2001), and this habitat preference is most expressed at the displaying period. Since air wires modify the structure of the landscape, it should have effect on the displaying site selection of adult males as the presence of power lines can potentially lead to rejection of certain parts of potential displaying sites thus reducing the extent of potentially acceptable ones.

\section{Materials and methods}

\section{The study area}

The study area is located at the UpperKiskunság region in Central Hungary. This area is characterized by large-scale mosaics of unwooded grasslands and ploughfields, hosting the largest Pannonian Great Bustard population, which, in fact still shows continuous increase (Práger 2005). Major part of the area is designated as a Special Protection Area in the NATURA 2000 network (HUKN10001 and HUKN10002). The core area of the Great Bustard population (including the displaying and partly the nesting sites) falls under national protection, forming parts of Kiskunság National Park. In this issue, data originating from the above mentioned NATURA 2000 sites is being analysed.

\section{Data collection}

Field data on displaying Great Bustards were collected between 2004 and 2011. ArcPad software running on handheld GPS devices was used to record the location of displaying sites. Displaying sites cover the location presence of adult male Great Bustards showing displaying behaviour independently the number of individuals. The estimated centre of the occupied displaying sites were recorded as points, however in cases of larger flocks with strong competition it might reach an area up to 4 hectares $(200 \mathrm{~m} \times 200 \mathrm{~m})$.

During the field observations, in order to avoid any kind of anthropogenic affect disturbing the displaying Great Bustards, displaying sites were approached in a 500$1000 \mathrm{~m}$ distance. From this distance, the location of displaying sites could be esti- 
mated with the precision of 50-100 m using the available vector map elements (e.g. the location of field roads, paths, border of land units etc.). In the case of the Great Bustard, amongst suitable light conditions it is fairly easy to determine the age and sex of the observed individuals. During the field work all the individuals, regardless their age and sex group and behaviour, were recorded. In spite of that, in this issue only data on displaying adult males is being analysed.

\section{Statistical methods}

Our field observations and preliminary analyses revealed that Great Bustards reject the close neighbourhood of medium voltage power lines (MVPLs) as displaying sites. To determine the influence of location of MVPLs on spatial distribution of displaying sites, two alternative analytical methods were used.

'Method I' was used to describe and to evaluate the shift in location of displaying sites caused by the rejection of the potential displaying sites close to MVPLs. In this method, displaying sites were rendered based on their distance from the nearest MVPL. Regarding this method the following consecutive steps were performed:

a) The distance from the nearest MVPL was measured in the case of every single displaying site and random generated points.

b) Displaying sites and random points were ordered based on the distance measured from the nearest MVPL.

c) The following measures were computed:

- the shortest distance between a particular displaying site and a MVPL (which represent the distance, that male Great Bustards minimally keep from MVPLs during displaying site selection, i.e. the width of totally rejected zone surrounding MVPLs)
- the portion of the displaying sites located within $500 \mathrm{~m}$ from the closest MVPL (it can be regarded as a critical distance for the Great Bustards in Central Hungary, since individuals almost never move further when a person or a car appears in such a distance)

- the minimal distance between displaying sites and MVPLs kept by $75 \%$ of locations

- the minimal distance between displaying sites and MVPLs kept by 95\% of locations

'Method II' was used for comparison of the distribution of real (occupied) displaying sites and random points in overlapping belts with increasing width surrounding MVPLs. This method was used to determine the width of piece of land surrounding MVPLs where significant negative effect can be observed. Regarding this method the following consecutive steps were performed:

a) Overlapping concentric polygons were created which represented the surroundings of the MVPLs with width of 400, 800, 1500, 3000, 3500, $4000 \mathrm{~m}$, respectively.

b) As preliminary data analyses revealed the number of observed displaying sites (which was 221, see the results section) 200 random points were placed in the study area within the frames of a Monte Carlo simulation (the RND function of MS Excel was used to create the coordinates of random points).

c) The probability of occurrence of a displaying site within a particular belt was calculated as the ratio between the number of displaying sites located in the certain belt and the total number of observed displaying sites.

d) The probability of occurrence of a random point within a particular belt was calculated as the ratio between the number of 


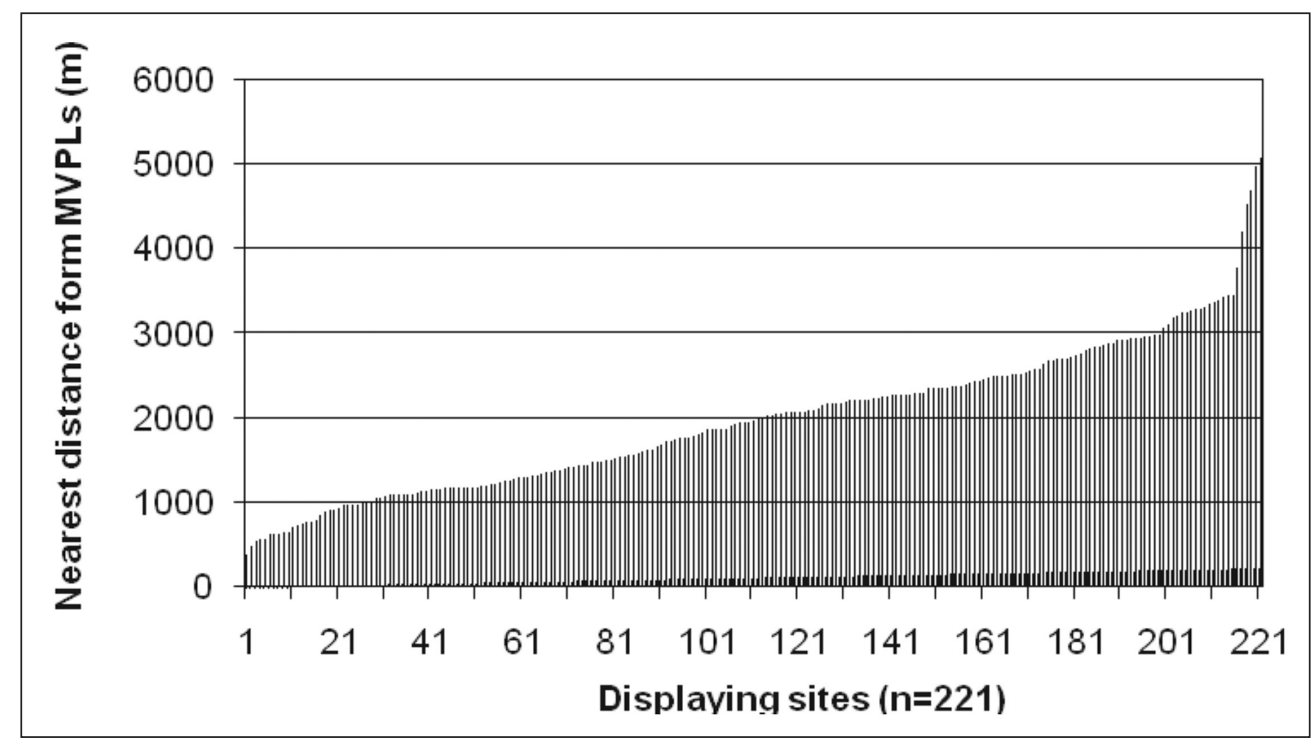

Figure 1. Nearest distances between displaying sites and above-ground MVPLs

1. ábra A dürgőhelyek távolsága a legközelebbi középfeszültségü légvezetéktől

random points located in the certain belt and the total number of points.

e) Welch-test was used for comparison of these probabilities.

\section{Results}

\section{The spatial distribution of displaying sites with respect to the distance from above-ground MVPLs}

The distribution of distances between above-ground MVPLs and observed displaying sites $(n=221)$ is shown at Figure 1 .

There were no birds showing displaying behaviour within the 383 meters surroundings of MVPLs, which can be interpreted as the distance of total rejection of a particular location as a displaying site by the Great Bustards. Within the 500 meters buffer of MVPLs only 2 displaying sites were observed. Ninety-five percent of displaying sites were located at a distance of 740 meters or more from above-ground MVPLs.
Seventy-five percent of displaying sites were located at least 1240 meters far from MVPLs (Table 1).

In the case of random points there were 86 points within the 500 meters buffer zone around MVPLs. Ninety-five percent of random points were at least 42 meters far from MVPLs. Seventy-five percent of random points were at least 225 meters far from MVPLs (Table 1).

The distribution of real displaying sites and random points located in particular discrete sized belts around the above ground medium voltage power lines is shown in Figure 2.

\section{The distance from above-ground} medium voltage power lines at which Great Bustards show rejection during display

The results of Welch-tests show that even at a distance of 3000 meters statistical difference can be detected between the probability of observation of Great Bustard display- 


\begin{tabular}{|l|c|c|l|c|}
\hline & $\begin{array}{l}\text { Minimal distance } \\
\text { from MVPLs (m) }\end{array}$ & $\begin{array}{l}\text { Portion of points } \\
\text { located within } \\
\text { 500m distance from } \\
\text { MVPLs }\end{array}$ & $\begin{array}{l}\text { The minimal dis- } \\
\text { tance from MVPLs } \\
\text { kept by 95\% of dis- } \\
\text { playing males (m) }\end{array}$ & $\begin{array}{l}\text { The minimal dis- } \\
\text { tance from MVPLs } \\
\text { kept by 75\% of dis- } \\
\text { playing males (m) }\end{array}$ \\
\hline Random points & N.A.* & $43.0 \%$ & 42 & 225 \\
\hline $\begin{array}{l}\text { Occupied } \\
\text { displaying sites }\end{array}$ & 383 & $0.90 \%$ & 740 & 1240 \\
\hline
\end{tabular}

Table 1. Comparison of distances measured from MVPLs and the spatial distribution of points in the case of random points and occupied displaying sites. * this measure has not been calculated since it has no biological meaning

1. táblázat A Monte-Carlo szimulációval előállított random pontok és a valóságban elfoglalt lekek távolsága és térbeli eloszlása. * ez az érték nem bír biológiai jelentéssel, így nem lett megadva

ing sites and the probability of occurrence of random points in the surroundings of MVPLs (Table 2).

Data show that the rejection effect of MVPLs ceases between 3000 and 3500 meters. Between these two values linear interpolation of ts values was applied. Accordingly, the distance where statistical significance changes from high $(p=0.01)$ to low $(\mathrm{p}=0.05)$ was calculated as 3324 meters, and the distance where statistically there is no difference between the real and random points was calculated as 3480 meters.

\section{Discussion}

The negative effects of above ground wires (power lines, optical cables etc.) has been

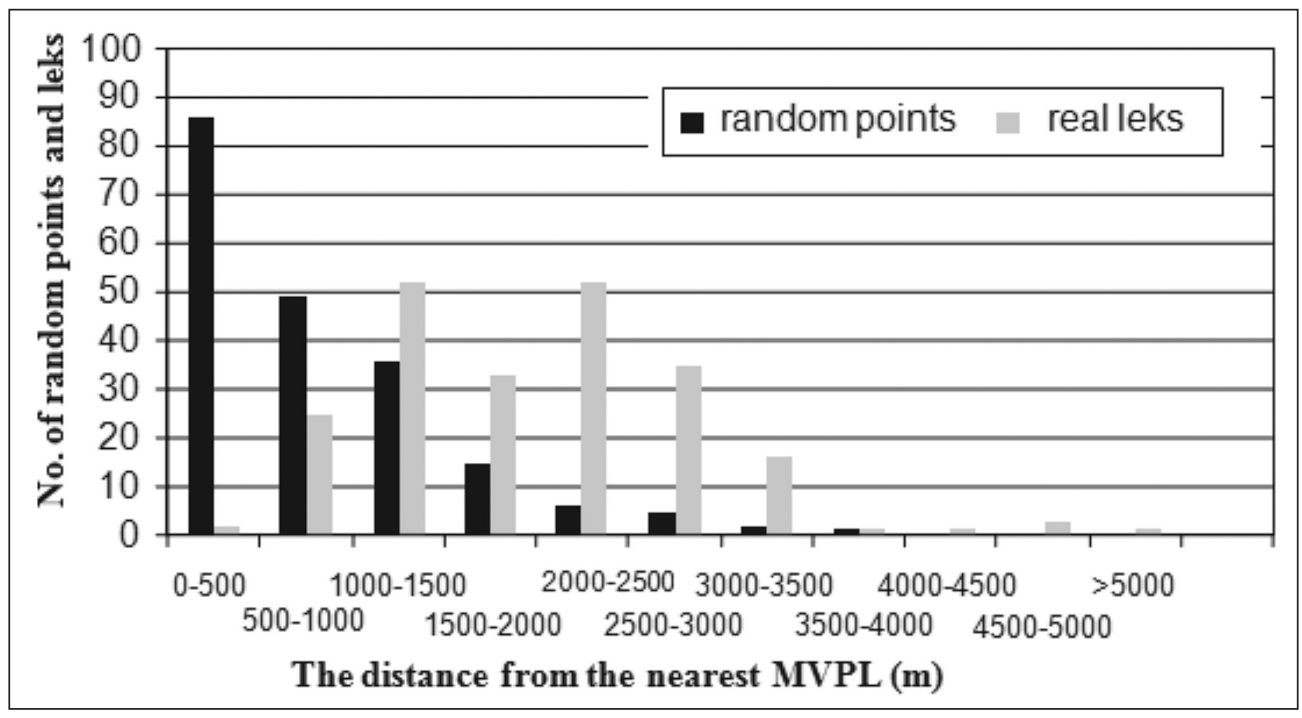

Figure 2. Distribution of the numbers of real displaying sites and random points according to distances from MVPLs

2. ábra A valós lekek és a random pontok térbeli eloszlása és száma a középfeszültségü légvezetékektől mért távolság függvényében 


\begin{tabular}{|l|l|c|c|c|c|c|c|c|}
\hline & & $\mathbf{4 0 0 m}$ & $\mathbf{8 0 0 m}$ & $\mathbf{1 5 0 0 m}$ & $\mathbf{3 0 0 0 m}$ & $\mathbf{3 5 0 0 m}$ & $\mathbf{4 0 0 0 m}$ & $\mathbf{4 5 0 0 \mathrm { m }}$ \\
\hline $\begin{array}{l}\text { Probability } \\
\text { of presence } \\
\text { of a random } \\
\text { point }\end{array}$ & Average & $\mathbf{0 . 3 8 0}$ & $\mathbf{0 . 5 9 5}$ & $\mathbf{0 . 8 5 5}$ & $\mathbf{0 . 9 8 5}$ & $\mathbf{0 . 9 9 5}$ & $\mathbf{0 . 9 9 9}$ & $\mathbf{0 . 9 9 9}$ \\
\hline & $\begin{array}{l}\text { Standard } \\
\text { deviation }\end{array}$ & 0.487 & 0.492 & 0.353 & 0.122 & 0.061 & 0.000 & 0.000 \\
\hline & $\begin{array}{l}\text { Standard } \\
\text { error of } \\
\text { the mean }\end{array}$ & 0.034 & 0.035 & 0.025 & 0.009 & 0.004 & 0.000 & 0.000 \\
\hline $\begin{array}{l}\text { Probability } \\
\text { of presence } \\
\text { of observed } \\
\text { displaying } \\
\text { sites }\end{array}$ & \begin{tabular}{l} 
Average \\
\hline
\end{tabular} & $\mathbf{0 . 0 0 5}$ & $\mathbf{0 . 0 7 2}$ & $\mathbf{0 . 3 5 7}$ & $\mathbf{0 . 9 0 0}$ & $\mathbf{0 . 9 7 3}$ & $\mathbf{0 . 9 9 2}$ & $\mathbf{0 . 9 9 5}$ \\
\hline & $\begin{array}{l}\text { Standard } \\
\text { deviation }\end{array}$ & 0.067 & 0.260 & 0.480 & 0.300 & 0.163 & 0.087 & 0.068 \\
\hline & $\begin{array}{l}\text { Standard } \\
\text { error of } \\
\text { the mean }\end{array}$ & 0.005 & 0.017 & 0.032 & 0.020 & 0.011 & 0.006 & 0.005 \\
\hline & ts & $\mathbf{1 0 . 8 1 9 * *}$ & $\mathbf{1 3 . 4 2 1 * *}$ & $\mathbf{1 2 . 1 8 6 * *}$ & $\mathbf{3 . 8 5 2 * *}$ & $\mathbf{1 . 8 8 0}$ & $\mathbf{1 . 0 9 2}$ & $\mathbf{0 . 7 3 5}$ \\
\hline & df & $\mathbf{2 0 5 . 8 8 7}$ & $\mathbf{2 9 5 . 0 1 8}$ & $\mathbf{4 0 2 . 4 6 4}$ & $\mathbf{2 9 6 . 5 9 6}$ & $\mathbf{2 8 6 . 2 8 4}$ & $\mathbf{2 2 0 . 0 0 0}$ & $\mathbf{2 2 0 . 0 0 0}$ \\
\hline
\end{tabular}

Table 2. Comparison of the probabilities of presence of random points and observed displaying sites in the surroundings of above ground medium voltage power lines (represented as belts of particular width) by Welch-tests. ${ }^{* *}$ indicates high level $(p=0.01)$ of significance

2. táblázat A random pontok és a valós lekek előfordulási valószínűségének összehasonlítása Welchpróbával a középfeszültségű vezetékek meghatározott szélességű környezetében. **erősen szignifikáns különbség $(p=0,01)$

reported in several studies (as examples, see Bevanger 1998, Lehman et al. 2007). Usually, electrocution (Lehman et al. 2007) and collision with wires (Martin \& Shawn 2010) are regarded as killing factors for birds, including individuals of species with endangered or vulnerable status. However, considering that the presence of above ground power lines can potentially reduce the extent of suitable (or preferred) feeding/breeding/resting grounds of birds, until recently surprisingly few studies has focused on the potential negative effects of power lines on habitat selection or habitat use of birds (e.g. Ballasus \& Sossinka 1996).

Our results revealed that male Great Bustards totally reject the sites located within
$350-400 \mathrm{~m}$ or closer to medium voltage power lines as displaying sites. This distance is roughly equivalent with the observed safety distance usually kept by Great Bustards, i.e. these birds take wing when noticing potential threatening factors (unknown vehicles, persons etc.) within this distance.

Furthermore, potential displaying sites located at a distance between 500 and 1000 $\mathrm{m}$ far from MVPLs are underrepresented as real displaying sites, indicating the relative rejection of these potential displaying sites.

Based on the comparison with random points, occupied (used) displaying sites are overrepresented in the belt located in a distance between 1000 and $3500 \mathrm{~m}$ far from MVPLs, indicating the shift of dis- 
playing site selection from locations closer to MVPLs toward the more distant locations. However, the rejection of location closer (within $1000 \mathrm{~m}$ ) to MVPLs is so expressed, that the portion of real displaying sites located at a distance within $3500 \mathrm{~m}$ from MVPLs is still smaller than the expected value (based on the results of the Monte Carlo simulation). Accordingly, the overall negative effects influence much larger part of the potential displaying grounds.

The above mentioned phenomena appoint on the fact that MVPLs reduce the extent of suitable displaying sites of the Great Bustards in the Upper-Kiskunság region. Accordingly, installation of new above-ground power lines (and other kind of wires, such as high voltage power lines, optical cables, etc.) would further reduce the extent of suitable displaying sites. Presumably, the installation of new power lines could fragment the traditional displaying grounds, which could easily lead to the total rejection of those fragments of the potential displaying grounds which are characterized with suitable landscape structure but are too small in extent as the Great Bustard prefers large open areas as displaying sites.

It has been previously revealed that the Great Bustards are quite conservative in choosing displaying sites. While breeding females are reported to (re)occur at those locations where no breeding has been observed for decades as the population grows, new displaying grounds has not been reported. Accordingly, the sustenance of traditional displaying grounds forms one of the basic conditions for the preservation of core populations of the Great Bustard.
As the chance for the formation of new displaying sites is low due to the density of MVPLs, it would be reasonable to underground existing above ground cables at potential displaying sites.

Also, taking into consideration of the fact that there is another well known negative effect of power lines, i.e. collision of birds with wires, which represents a major killing factor for the Great Bustard (Reiter 2000), it would be reasonable to underground the existing above ground cables (i.e. replace those with underground cables). Although there are some solutions for reducing the risk of collision, such as the application of flight diverters on wires (Alonso et al. 1994), undergrounding of power lines would be the ultimate solution (Raab et al. 2011, Raab et al. 2012).

\section{Acknowledgements}

We'd like to thank to the Kiskunság National Park Directorate for the helpful background and support of the field work, which resulted the monitoring database of present work. We are specially thankful for the GIS data management to Róbert Aleksza.

Between 2004 and 2008 monitoring activity has been carried out with the financial support of the EU LIFE foundation. For the coordination and project management of 'The protection of Great Bustard in Hungary' OTISHU project special thanks goes to András Bankovics and Marietta Sipos, for the data collection within this period to Ákos Németh. 


\section{References}

Alonso, J. C., Alonso, J. A. \& Muñoz-Pulido, R. 1994. Mitigation of bird collisions with transmission lines through groundwire marking. Biological Conservation 67(2): 129-134. DOI: 10.1016/0006-3207(94)90358-1

Ballasus, H. \& Sossinka, R. 1996. The impact of power lines on field selection and grazing intensity of wintering White-fronted and Bean Geese Anser albifrons, A. fabalis. - Journal of Ornithology $138: 215-228$.

Bevanger, K. 1998. Biological and conservation aspects of bird mortality caused by electricity power lines: a review. - Biological Conservation 86(1): 67-76. DOI: 10.1016/S0006-3207(97)00176-6

Bevanger, K. \& Brøseth, H. 2001. Bird collisions with power lines - an experiment with ptarmigan ( $\mathrm{La}$ gopus spp.). - Biological Conservation 99(3): 341-346. DOI: 10.1016/S0006-3207(00)00217-2

Janss, G. F. E. 2000. Avian mortality from power lines: a morphologic approach of a species-specific mortality. - Biological Conservation 95(1): 353-359. DOI: 10.1016/S0006-3207(97)00176-6

Lane, S. J., Alonso, J. C. \& Martín, C. A. 2001. Habitat preferences of Great Bustard Otis tarda flocks in the arable steppes of central Spain: are potentially suitable areas unoccupied? - Journal of Applied Ecology 38: 193-203. DOI: 10.1046/j.13652664.2001.00577.x

Lehman, R. N., Kennedy, P. L. \& Savidge, J. A. 2007. The state of the art in raptor electrocution re- search: A global review. - Biological Conservation 136(2): 159-174. DOI: 10.1016/j.biocon.2006.09.015

Martin, G. R. \& Shaw, J. M. 2010. Bird collisions with power lines: Failing to see the way ahead? - Biological Conservation 143(11): 2695-2702. DOI: 10.1016/j.biocon.2010.07.014

Práger, A. 2005. Population estimates, trends and synchronised census of Great Bustard (Otis tarda) in Hungary. - Aquila 112: 143-150.

Raab, R., Schütz, C., Spakovszky, P., Julius, E. \& Schulze, C. H., 2012. Underground cabling and marking of power lines: conservation measures rapidly reduced mortality of WestPannonian Great Bustards Otis tarda. - Bird Conservation International 22: 299-306. DOI: 10.1017/ S0959270911000463

Raab, R., Spakovszky, P., Julius, E., Schütz, C. \& Schulze, C. H. 2011. Effects of power lines on flight behaviour of the West-Pannonian Great Bustard Otis tarda population. - Bird Conservation International 21: 142-155. DOI: 10.1017/ S0959270910000432

Reiter, A. S. 2000. Casualties of Great Bustards (Otis tarda L.) on overhead power lines in the western Weinviertel (Lower Austria). - Egretta 43: 37-54.

Vadász, Cs. \& Lóránt, M. 2014. Key mortality causes of the Great Bustard Otis tarda in Central Hungary: an analysis of known fatalities. - Ornis Hungarica 22(2): $32-41$.

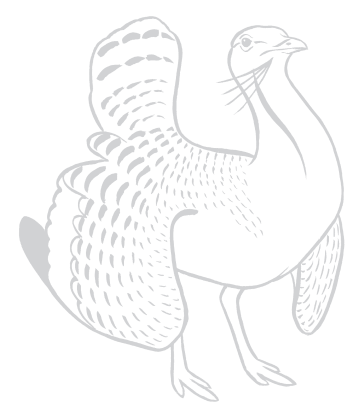

